\title{
Host resistance to malaria: using mouse models to explore the host response
}

\author{
Rhea Longley • Clare Smith • Anny Fortin • \\ Joanne Berghout • Brendan McMorran • \\ Gaétan Burgio $\cdot$ Simon Foote $\cdot$ Philippe Gros
}

Received: 8 August 2010/Accepted: 3 November 2010

(C) Springer Science+Business Media, LLC 2010

\begin{abstract}
Malaria is a disease that infects over 500 million people, causing at least 1 million deaths every year, with the majority occurring in developing countries. The current antimalarial arsenal is becoming dulled due to the rapid rate of resistance of the parasite. However, in populations living in malaria-endemic regions there are many examples of genetic-based resistance to the severe effects of the parasite Plasmodium. Defining the genetic factors behind host resistance has been an area of great scientific interest over the last few decades; this review summarizes the current knowledge of the genetic loci involved. Perhaps the lessons learned from the natural variation in both the human populations and experimental mouse models of infection may pave the way for novel resistance-proof antimalarials.
\end{abstract}

\section{Background}

Despite significant technical and medical advances in the past 100 years for controlling malaria infection, the prospect of eradicating the disease remains daunting. In part, this is due to the many socioeconomic factors faced by the countries most affected, but a major concern is also the problem of parasite drug resistance. All current antimalarial drugs target the parasite. The enormous capacity for genetic variation in the parasite in conjunction with the effect of the

R. Longley · C. Smith · B. McMorran · G. Burgio ·

S. Foote $(\square)$

Menzies Research Institute, University of Tasmania,

17 Liverpool Street, Hobart, TAS 7000, Australia

e-mail: Simon.Foote@utas.edu.au

A. Fortin · J. Berghout $\cdot$ P. Gros

Department of Biochemistry, McGill University, 3649

Promenade Sir William Osler, Montreal, QC H3G 0B1, Canada highly selective nature of drug treatment on the parasite's survival has resulted in the rapid development of drugresistant strains to all currently used antimalarial agents. Chloroquine, once the frontline antimalarial drug, is now virtually useless in all malaria-endemic regions. Parasite strains have recently been isolated from Cambodia that display increasing resistance to artemisinin, a drug that has only recently been introduced into the antimalarial armamentarium (Dondorp et al. 2009). With the dramatic rise and spread of resistance against these parasite-directed drugs, a new approach is desperately needed.

With this in mind, this review instead focuses on hostprotective mechanisms, particularly those with a genetic basis. Malaria has coexisted with humans for many millennia, and given the high mortality rate it causes, has had a profound impact on the human genome. A variety of polymorphisms and mutations that protect against infection and the symptoms of the disease have arisen in human populations living in malaria-endemic regions of the world. Many protective polymorphisms affect the red blood cell (RBC) in which the parasite resides during the symptomatic stages of the disease. The red cell sustains the greatest parasite mass for the longest period of time, and for the parasite P. falciparum, it is the target of an immune response that can clear the host of all parasites. It is therefore not surprising that a subversive battle has been fought between the host and parasite genomes for thousands of years, the battleground being the red cell; the outcome ultimately deciding the result of infection for the human host and the continuing cycle of the parasite.

The most severe and life-threatening manifestation of Plasmodium falciparum infection is cerebral malaria (CM). Human CM (HCM) mortality and morbidity in regions of malaria endemicity is particularly important in children under the age of 5 , a population of patients who have not yet developed protective immunity against Plasmodium 
parasites. HCM is caused when infected erythrocytes are retained and become trapped in the body microvasculature, most notably capillaries and venules of the brain. This leads to an excessive, localized host-driven inflammatory response, resulting in hypoxia, loss of blood-brain barrier integrity, local hemorrhage, and additional complications. Symptoms include impaired consciousness with fever, generalized convulsions, and neurological abnormalities, and coma that lasts for 24-72 h, initially rousable and then unrousable. Additional complications of HCM include increased intracranial pressure, hemiplegia, encephalopathy, and acute renal failure with uremia; HCM is fatal in approximately $20 \%$ of patients (Mishra and Newton 2009). Treatment options are few and include high-dose quinine and/or artemisinin, as well as several adjunctive measures (antipyretics, microcirculatory flow, anticonvulsants, iron chelators) where efficacy remains debatable (Mishra and Newton 2009). The very high incidence of Plasmodium infection in populations living in regions of malaria endemicity (which is assumed to be constant during the wet season) and the fact that most HCMassociated deaths occur in young children have favored alteration of the human gene pool by malarial parasites.

Here we focus on what is known about genetic-based host resistance in both human populations and experimental mouse models of malaria and suggest how this research could be translated into novel antimalarial therapies that may avoid the problem of parasite resistance common to the current generation of therapeutics.

\section{Natural resistance to malaria in human populations}

Human genetics has long been associated with variation in susceptibility to numerous infectious diseases. Of all diseases that impact the human population, malaria has exerted the largest measurable level of selective pressure on our genome. Haldane (1949) was the first to recognize the importance of host genetics in malaria resistance when he postulated that the high rates of thalassemia in Mediterranean populations were due to a heterozygous advantage afforded to carriers. Since this initial observation, numerous other mutations that have an impact on the host resistance to malaria have been identified. These mutations target mainly red cell proteins, factors involved in the sequestration of parasites as well as immune response variants. These have often been initially suggested through coincidence of malarial endemicity and increased mutation frequency. However, in some cases a molecular basis for disease resistance has also been demonstrated, as shown in Table 1 and further detailed below.

Genetic epidemiological studies, linkage studies, and association studies in affected human populations have pointed to a complex genetic component of resistance/ susceptibility to HCM, including a number of candidate genes such as erythrocyte polymorphisms (hemoglobinopathies) and genes involved in early inflammatory or innate immune response. These studies encompass a large body of literature that is not reviewed here. The reader is referred to excellent reviews on human host protection factors by Bongfen et al. (2009), Kwiatkowski and Luoni (2006), and Verra et al. (2009).

Recent genome-wide association approaches designed to discover novel loci that control malaria susceptibility have been disappointing, in part due to challenges in applying technologies developed for Caucasian genetic disease studies to Africans (Jallow et al. 2009). There is a large degree of genetic heterogeneity in African populations, making it more difficult to replicate the findings

Table 1 Examples of human polymorphisms associated with protection from malaria and the postulated mechanisms of resistance

\begin{tabular}{|c|c|c|}
\hline Polymorphism/locus & Hypothesized mechanism & References \\
\hline Sickle cell anemia & $\begin{array}{l}\text { Early clearance of infected RBCs } \\
\text { Reduced parasite growth and invasion }\end{array}$ & $\begin{array}{l}\text { Ayi et al. 2004; Fortin } \\
\text { et al. 2002; Friedman } 1978\end{array}$ \\
\hline$\alpha$-Thalassemia & $\begin{array}{l}\text { Oxidative stress } \\
\text { Immunological memory }\end{array}$ & $\begin{array}{l}\text { Flint et al. 1986; Williams } \\
\text { et al. } 1996\end{array}$ \\
\hline$\beta$-Thalassemia & Early clearance of infected RBCs & Ayi et al. 2004 \\
\hline Glucose-6-phosphate-dehydrogenase deficiency & Reduced parasite growth & $\begin{array}{l}\text { Reviewed in Ruwende } \\
\text { and Hill } 1998\end{array}$ \\
\hline Band 3 ovalocytosis & Reduced parasite invasion & Jarolim et al. 1991 \\
\hline Duffy negative antigen & $\begin{array}{l}\text { Disruption of the GATA motif in the Duffy gene, } \\
\text { resulting in absence of invasion by } P \text {. vivax }\end{array}$ & Tournamille et al. 1995 \\
\hline HLA class 1 antigen (HLA-Bw53) & $\begin{array}{l}\text { Possibly destruction of liver-stage parasites } \\
\text { by cytotoxic T cells }\end{array}$ & Hill et al. 1991 \\
\hline HLA class II haplotype (DRB1*1302-DQB $1 * 0501)$ & Increased parasite clearance & Hill et al. 1991 \\
\hline TNF- $\alpha$ variants & $\begin{array}{l}\text { Regulation of TNF- } \alpha \text {, linked to both } \\
\text { pathology and protection }\end{array}$ & McGuire et al. 1994 \\
\hline
\end{tabular}


between regions. Future genome-wide association studies will require the concerted effort of large international collaborations and more tailored genetic variation detection technologies. While researchers undertake this effort, another way to overcome the limitations of human studies has been to use experimental mouse models of malaria.

\section{Utilizing the mouse to model human susceptibility}

The parasite causing malaria infection, Plasmodium, infects not only humans; several species of Plasmodium have the ability to cause malaria in animals, including rodents. The most commonly used to infect laboratory mice are $P$. chabaudi, $P$. yoelii, $P$. berghei, and $P$. vinckei. Mice are considered a comparable genetic model to humans: There is a high degree of genomic conservation (99\%) (Pennacchio 2003), and it is well established that mice also exhibit natural differences in susceptibility to malarial infection (Greenberg et al. 1954). Murine models of malaria enable complex traits to be dissected in large crosses generated between resistant and susceptible strains, and allow the control of environmental factors such as parasite dose, strain and virulence, the route of infection, and nutritional intake (Fortin et al. 2002). Mice are also genetically tractable; the inbred strains of mice are genetically well defined and gene effects can be isolated through breeding. Their very large reproductive capacity is also advantageous, enabling studies of linkage analysis and positional cloning. The genome sequence of many inbred strains of mice is now available. In spite of recent criticism on the benefits mouse models provide in malaria studies (White et al. 2010), they have provided significant insight into host-protective mechanisms, as encapsulated in the robust responses to this article (Carvalho 2010; Hunt et al. 2010; Renia et al. 2010; Riley et al. 2010; Stevenson et al. 2010). As we discuss below, mouse malaria models in conjunction with applications in murine genetics provide a powerful and valuable way to discover novel mechanisms of host protection that may be amenable to the development of novel therapeutics.

$P$. chabaudi infections share a number of features that are typical of $P$. falciparum in humans. These include symptoms such as anemia, splenomegaly, and hepatomegaly. Sequestration of infected erythrocytes in the liver and spleen is observed, as are the development of analogous blood-stage antigens and the suppression of B- and T-cell responses (although cerebral disease is not a feature of this species) (Hernandez-Valladares et al. 2005; Min-Oo et al. 2007b; Weatherall et al. 2002). Importantly, P. chabaudi has also been used to recapitulate the protective effects of a number of human polymorphisms in conjunction with strains of mice carrying the equivalent mutations. However, P. chabaudi cannot be used as a model for cerebral malaria.
Although no animal model accurately mimics all aspects of CM in humans, infection of mice with Plasmodium berghei ANKA $(\mathrm{PbA})$ reproduces many of its characteristics. Experimental cerebral malaria (ECM) induced by infection with $\mathrm{PbA}$ is defined by the appearance of neurological symptoms, including ataxia, hind limb paralysis, deviation of the head, and coma, with death occurring between 6 and 10 days following infection. Death by ECM occurs with low levels of parasitemia, typically less than $20 \%$ parasitized erythrocytes depending on the mouse strains used (Hunt et al. 2006). Conversely, mouse strains naturally resistant to ECM (such as BALB/c mice) develop hyperparasitemia and severe anemia, with death occurring about 3 weeks after infection. Similar to what is observed in humans, sequestration in the brain microvasculature of $\mathrm{PbA}$-infected mice has been documented in some studies (de Souza et al. 2010; Francischetti 2008; Sanni et al. 2004; Stevenson et al. 2010). Similarly, a correlation between sequestered parasite biomass and disease severity has also been demonstrated (Amante et al. 2007; White et al. 2010). Other ECM features shared by HCM patients and PbAinfected mice include reversal of symptoms, platelet activation, and coagulopathy (Cox and McConkey 2010; Francischetti 2008). Studies in the ECM model have provided important clues for understanding the role of the immune response in HCM, which is difficult to study in human subjects for ethical reasons (de Souza et al. 2010). In addition, although controversial, research on adjunctive therapy in the ECM model has driven clinical research studies in human subjects (de Souza et al. 2010; White et al. 2010) (http://www.controlled-trials.com/mrct/search. html).

There have been two types of genetic analysis conducted in mouse models of malaria. The first is the reverse genetics approach in which mouse stocks bearing targeted mutations in candidate genes have been assessed for modulation of Plasmodium species. The second is the forward genetics approach in which inbred mouse strains showing different degrees of susceptibility to Plasmodium species have been analyzed to map the major gene effects regulating the differential response. Studies from both approaches are reviewed below.

\section{Genetics of host resistance to $P$. chabaudi and $P$. yoelii}

Infection of any one strain of mouse with $P$. chabaudi leads to a reproducible infection and a high rate of concordance between parasite growth kinetics and outcome to infection. However, there is considerable variability in both the rate of increase of parasites in circulation and the outcome of infection between inbred mouse strains. Of the inbred mouse strains, C57BL/6, BALB/c, DBA/1, C57BL/10, SPRET/Ei, and 129/SvJ are resistant when infected with 
P. chabaudi, as shown by survival and decreased parasitemia. SJL, C3H/He, NC/Jic, DBA/2, CBA/J, SM/J, $\mathrm{MOLF} / \mathrm{Ei}$, and $\mathrm{A} / \mathrm{J}$ are all susceptible strains and exhibit higher parasitemia at the peak of infection and a high mortality rate, with death usually occurring the second week after infection (Fortin et al. 2002; Hernandez-Valladares et al. 2005). This implies that host genetic differences underlie susceptibility to malarial infection. The genetic basis is likely to be complex, and although not fully elucidated, several quantitative trait loci (QTLs) that determine resistance or susceptibility to $P$. chabaudi infection (Char loci) have been identified. Phenotypes analyzed include parasitemia and associated kinetics and survival. At present, ten loci associated with the control of parasitemia in $P$. chabaudi, six loci linked to cerebral malaria in $P$. berghei infection, and one locus associated with susceptibility to $P$. yoelii infection have been reported (Table 2). The genetics of $P$. berghei infection are discussed in the next section.

Independently, two groups published papers in 1997 that first identified loci controlling parasitemia during $P$. chabaudi malarial infection (Foote et al. 1997; Fortin et al. 1997). Charl and char2 were mapped to chromosomes 9 and 8, respectively, by Foote et al. using linkage analyses of the F2 generation of crosses between two susceptible strains, SJL and $\mathrm{C} 3 \mathrm{H} / \mathrm{He}$, and the resistant strain C57BL/6 (Foote et al. 1997). These loci controlled survival and peak parasitemia. At the same time, Fortin et al. mapped the same char 2 locus controlling parasitemia using both backcrossing and intercrossing between $\mathrm{A} / \mathrm{J}$ (susceptible) and C57BL/6 (Fortin et al. 1997). A further study analyzing a $\mathrm{NC} / \mathrm{Jic}$ and $129 / \mathrm{SvJ}$ cross found that parasitemia during $P$. yoelii infection mapped to a locus on chromosome 9, at the same location as charl, suggesting that this may represent a ubiquitous locus (Ohno et al. 2001). Additional crosses between C57BL/6 and C3H/HeJ also found a linkage peak over char2. Further studies of subcongenic lines for char2 have uncovered considerable complexity to this locus, with at least two loci mapping to a similar region (Lin et al. 2006).

A separate locus, char3, was identified on chromosome 17 from a [C3H/Hex C57BL/6]F2 cross (Burt et al. 1999). Unlike charl and 2, char3 was mapped using the time of peak parasitemia rather than the outcome to infection or the magnitude of peak parasitemia. It was hypothesized that char3 controls the rate of parasite clearance. This locus was most closely linked to markers in the mouse major histocompatibility complex (H-2), which had previously been shown to be linked to resistance to malarial infection in mice (Wunderlich et al. 1988). C57BL/6 animals carrying a donor char3 interval, however, were considerably more resistant to death from $P$. chabaudi infection than the otherwise resistant C57BL/6, a result that was not predicted from the original cross, indicating that there may be epistatic interactions at work.

The disadvantage of the methods used to identify charl-3 is that the chromosomal regions mapped were

Table 2 Genetic loci linked to murine malaria resistance and the method used to identify them, as well as the associated phenotype

\begin{tabular}{|c|c|c|c|c|c|c|}
\hline Murine parasite & Locus & Cross & Phenotype & Location & LOD or $\chi^{2}$ & Reference \\
\hline \multirow[t]{10}{*}{ P. chabaudi } & Charl & \multirow[t]{3}{*}{ Backcross and/or intercross } & Parasitemia & 9 & $6.6 / 9.1$ & Foote et al. 1997 \\
\hline & Char2 & & Parasitemia & 8 & 8.83 & Foote et al. 1997; Fortin et al. 1997 \\
\hline & Char3 & & Parasitemia & 17 & 5.0 & Burt et al. 1999 \\
\hline & Char4 & Recombinant congenic strains & Parasitemia & 3 & 6.57 & Fortin et al. 2001 \\
\hline & Char5 & \multirow[t]{4}{*}{ Advanced intercross lines } & Parasitemia & 5 & 2.16 & Hernandez-Valladares et al. 2004a \\
\hline & Char6 & & Parasitemia & 5 & 2.16 & Hernandez-Valladares et al. 2004a \\
\hline & Char7 & & Parasitemia & 17 & 5.75 & Hernandez-Valladares et al. 2004a \\
\hline & Char8 & & Parasitemia & 11 & 1.9 & Hernandez-Valladares et al. 2004b \\
\hline & Char9 & \multirow[t]{2}{*}{ Recombinant congenic strains } & \multirow[t]{2}{*}{ Parasitemia } & 10 & 4.74 & Min-Oo et al. 2007b \\
\hline & Charlo & & & 9 & 7.24 & Min-Oo et al. 2010 \\
\hline \multirow[t]{7}{*}{ P. berghei } & $\mathrm{a}$ & \multirow[t]{4}{*}{ Backcross and/or intercross } & Survival & 18 & $\chi^{2}=30.1$ & Nagayasu et al. 2002 \\
\hline & Berrl & & Survival & 1 & $\chi^{2}=18.98$ & Bagot et al. 2002 \\
\hline & Berr2 & & Survival & 11 & $\chi^{2}=16.51$ & Bagot et al. 2002 \\
\hline & cmsc & & Survival & 17 & $\chi^{2}=26.18$ & Ohno and Nishimura 2004 \\
\hline & Berr 3 & Intercross & Parasitemia & 9 & 4.9 & Campino et al. 2005 \\
\hline & Berr 4 & Intercross & Parasitemia & 14 & 3.42 & Campino et al. 2005 \\
\hline & Berr 5 & Intercross & Survival & 19 & 4.69 & Berghout et al. 2009 \\
\hline P. yoelii & Pymr & Backcross & Parasitemia & 9 & 4.4 & Ohno et al. 2001 \\
\hline
\end{tabular}

Location = chromosomal location

${ }^{a}$ Locus not designated by authors 
large and contained several hundred candidate genes due to low rates of recombination in the generation of F2 crosses (Darvasi and Soller 1995). The more recent use of congenic animals, recombinant congenic strains, and especially advanced intercross lines has sought to overcome these problems and has led to additional char loci being reported, and in one case identification of the underlying gene. Recombinant congenic strains (Mullerova and Hozak 2004) were used to identify a new malaria susceptibility locus on chromosome 3, char4. Fortin et al. (2001) developed a set of 33 recombinant congenic strains between the susceptible A/J (A) and resistant C57BL/6 (B). The strain AcB55 was shown to be highly resistant due to markedly reduced peak parasitemia, despite having susceptibility alleles at the charl and char2 loci. Linkage analysis of an F2 cross (parents AcB55 and A/J) mapped the peak parasitemia determinant to char4 (located on chromosome 3). Sequencing of candidate genes in this locus showed that resistance in the AcB55 recombinant congenic mouse was due to a loss-of-function mutation in the pyruvate kinase gene (Min-Oo et al. 2003). This led to the proposal that pyruvate kinase deficiency results in malaria resistance due to the primary defect causing hemolytic anemia that in turn results in an increased compensatory rate in erythropoiesis (Min-Oo et al. 2004). This study showed the power of the genetic approach, in particular using recombinant congenic lines to identify new mechanisms involved in the host response to malaria. Recently, polymorphisms in the human pyruvate kinase gene have been associated with protection against $P$. falciparum (Ayi et al. 2008).

Identification of additional char loci has been aided by the development of advanced intercross lines (AILs). AILs are produced by randomly and sequentially intercrossing a population generated from two initial inbred lines for at least eight generations, increasing the probability of recombination and providing a greater mapping resolution (Darvasi and Soller 1995). Hernandez-Valladares et al. used an F11 AIL from A/J and C57BL/6 parents to identify two significant host-response QTLs on chromosome 5, char 5 and char6, as well as a locus on chromosome 11 (char8), and confirmed the QTL already identified on chromosome 8 (char2) (Hernandez-Valladares et al. 2004a, b). They also resolved the previously named char3 locus on chromosome 17 into two loci, char3 and char7.

Recently, a ninth and a tenth locus associated with malarial resistance were identified on chromosomes 10 and 9, respectively. Char 9 was mapped to chromosome 10 $(\mathrm{LOD}=4.74)$ using an intercross of parents AcB55 and A/J that identified char4 (Min-Oo et al. 2007a). Char9 regulates the blood-stage replication of $P$. chabaudi independently of the pyruvate kinase gene originally found by these authors. Using gene expression analysis, they have identified two Vanin genes, Vnn1 and Vnn3, as the likely candidates responsible for the resistance associated with char9. Charl0 has recently been identified on chromosome $9(\mathrm{LOD}=7.24)$ in $[\mathrm{AcB} 62 \times \mathrm{CBA}-\mathrm{pk}] \mathrm{F} 2$; this locus modulates severity of malaria in a context of pyruvate kinase deficiency (Min-Oo et al. 2010). In addition, studies in mouse mutants have revealed further host genes associated with outcomes to $P$. chabaudi infection. Genes implicated in host resistance include immune system processes and RBC structural proteins (Table 3).

\section{Genetics of host resistance to P. berghei ANKA (PbA)}

Inbred strains of mice exhibit different responses to Plasmodium berghei ANKA ( $\mathrm{PbA})$, with susceptible strains such as C57BL/6 (B6) or CBA developing an acute cerebral syndrome within 6-7 days characterized by ataxia, paraplegia, seizures, and coma leading to uniform lethality by day 8-10 postinfection. On the other hand, resistant mice, including the BALB/c and wild-derived WLA/Pas strains, do not develop neurological symptoms/ECM but go on to succumb 2-4 weeks postinfection due to severe anemia caused by high levels of blood parasitemia. Using either the appearance of ECM or time of death following $\mathrm{PbA}$ infection as phenotypic markers of susceptibility, QTL mapping studies by whole-genome scanning in mice have detected a number of chromosomal regions regulating

Table 3 Single-gene defects associated with response to $P$. chabaudi

\begin{tabular}{llll}
\hline Gene ID & Gene name & Knockout effect on $P$. chabaudi infection & Reference \\
\hline TLR9 & Toll-like receptor 9 & Partially resistant & Hisaeda et al. 2008 \\
Taut & Taurine transporter & Decrease survival & Delic et al. 2010 \\
MIF & Macrophage migration inhibitory factor & Increased survival & McDevitt et al. 2006 \\
ANK-1 & Ankyrin-1 & Heterozygous mice show increased survival & Rank et al. 2009 \\
CD24/HSA & CD24/Heat stable antigen & Increased parasitemia & Nielsen et al. 1997 \\
Spna1 & Spectrin alpha-1 & Increased survival & Shear et al. 1991 \\
Csf 2 & Colony-stimulating factor 2 (granulocyte-macrophage) & Decreased survival & Riopel et al. 2001 \\
$I l 15$ & Interlukin-15 & Delayed parasite clearance & Ing et al. 2005 \\
\hline
\end{tabular}


response to $\mathrm{PbA}$ infection. The genetic determinants regulating differential susceptibility of C57BL/6 J (very susceptible) and $\mathrm{DBA} / 2 \mathrm{~J}$ (less susceptible) to $\mathrm{PbA}$ infection were studied in informative $\mathrm{F} 1$ and $\mathrm{F} 2$ mice. Resistance was found to be inherited in a recessive fashion and linked to two markers in the central portion of chromosome 18 (D18Mit123 and D18Mit202) (Nagayasu et al. 2002). The high degree of resistance to $\mathrm{PbA}$ infection of wild-derived mice was studied using informative backcross and F2 progeny between C57BL/6 J (susceptible) and wild-derived WLA/Pas mice (highly resistant). In such crosses, resistance to ECM was found to be dominant and under complex genetic control. Two loci, designated Berrl and Berr2, that control the appearance of ECM were initially mapped in backcross animals to chromosomes 1 (D1Mit221 near transforming growth factor $\beta 2, T g f b 2)$ and 11 (D1 1Mit338), respectively (Bagot et al. 2002). In a second study using a [C57BL/6 J X WLA] F2 cross, the same group showed that time of survival following $\mathrm{PbA}$ infection was controlled by Berrl (LOD $=6.4$ ) and by an additional locus on the distal portion of Chr 9 (LOD = 4.9; D9Mit18), which they designated Berr3. An additional weaker linkage on $\mathrm{Chr} 14$ (Berr4; D4Mit27; LOD = 3.42) was also detected in this study (Campino et al. 2005). Finally, the Cmsc locus mapping to the $\mathrm{H}-2$ region of chromosome 17 was found to affect susceptibility in progeny of CBA mice crossed with the resistant DBA/2 strain (Ohno and Nishimura 2004). In all cases, the detected QTLs span large chromosomal segments, and although there are a number of attractive positional candidates within their confidence intervals, the causative genes underlying their effect on survival time in $P$. berghei-infected animals have not been identified.

More recently, Berghout et al. (2009) used survival time to estimate susceptibility to $\mathrm{PbA}$ infection in an $\mathrm{F} 2$ cross $(n=257)$, and identified linkage to chromosome 19 $[$ Berr5, LOD $=4.69]$ that controls, in part, the differential response between resistant $\mathrm{BALB} / \mathrm{c}$ and susceptible C57BL/6 progenitors. BALB/c alleles convey increased survival through the cerebral phase of infection but have no quantitative effect on parasitemia during the later, anemic phase. The Berr5 locus colocalizes with three other immune loci, including Trl-4 (tuberculosis resistance), Tsiq2 (T-cell secretion of IL-4), and Eae19 (experimental allergic encephalitis 19), suggesting the possibility of a common genetic effect underlying these phenotypes. Potential positional candidates include the family of Ifit $1-3$ (interferon inducible protein with tetratricopeptide repeats $1-3)$, whose expression is differentially regulated in response to infection in a parental haplotype-specific fashion (Berghout et al. 2009).

Current evidence suggests that ECM in mice infected with $\mathrm{PbA}$ is caused in part by robust but detrimental localized inflammation in response to parasitized erythrocytes trapped in the brain microvasculature (Lamb et al. 2006; van der Heyde et al. 2006). Transcript profiling experiments have documented a substantial proinflammatory response in situ in infected tissues that is more pronounced in susceptible mice (Delahaye et al. 2006; Lovegrove et al. 2007; Sexton et al. 2004). Studies in mouse mutants have clearly demonstrated that early proinflammatory responses, including Th1 polarization of the immune response, are a central component of the hostdriven pathogenesis in ECM, and that mutations in genes from this pathway are protective against $\mathrm{PbA}$-induced ECM (Bongfen et al. 2009). Such studies are summarized in Table 4 and further detailed below.

For example, mice deficient in interferon- $\gamma$ (van der Heyde et al. 1997) and its downstream target, the key transcriptional activator STAT1 (P. Gros, unpublished), are resistant to $\mathrm{PbA}$-induced ECM. In the same type of analysis, it has been shown that the absence of functional lymphotoxin A (Togbe et al. 2008), Fas (Ohno et al. 2005), platelet factor 4 (Srivastava et al. 2008), and the complement component C5a (Patel et al. 2008) protects against ECM. Likewise, mutations in Tnfrlb (Piguet et al. 2002), Ccr5 (Belnoue et al. 2003), Cxcr3 (Campanella et al. 2008), CD14 (Oakley et al. 2009), CD8 (Oakley et al. 2009), and $C D 40$ (Piguet et al. 2001) increase survival times following infection with $\mathrm{PbA}$. Finally, mutations in members of the IRF family of transcriptional regulators, IRF1 (Senaldi et al. 1999) and IRF8 (Gros et al., unpublished), can also protect against ECM. In this case, protection appears concomitant with impaired production of IL12p40, and/or alterations in the number and type of natural killer (NK) cells and myeloid cells, including monocytes and CD11c + dendritic cells produced in these mice (P. Gros et al., unpublished). These observations support the hypothesis of a central role for immune-mediated pathology in ECM, with NK cells, $\mathrm{T}$ cells, platelets, and myeloid cells, including resident macrophages and dendritic cells, implicated in early inflammatory response and tissue injury.

\section{Future approaches to discovery of novel genes that provide resistance to infection}

Through the aforementioned mouse studies and earlier epidemiological studies on human populations, it can be seen that the genetic susceptibility to malaria and the host response to the infection is very complex. The genetic differences exhibited between mouse strains, as well as the polymorphisms identified in human populations, most likely control or contribute to a wide range of processes that influence the outcome of a malarial infection, including erythrocytic contributions and the immune response. So far most of the known human polymorphisms have limited 
Table 4 Single-gene defects associated with response to P. berghei

\begin{tabular}{|c|c|c|c|}
\hline Gene ID & Gene name & $\begin{array}{l}\text { Knockout effect on } \\
P . \text { berghei infection }\end{array}$ & Reference \\
\hline \multicolumn{4}{|c|}{ Immune system processes } \\
\hline Ccr 2 & Chemokine (C-C motif) receptor 2 & None & Belnoue et al. 2003 \\
\hline$C d 1$ & CD1 antigen & Increased survival & Hansen et al. 2003 \\
\hline$C d 8$ & CD8 antigen & Increased survival & Oakley et al. 2009 \\
\hline Cd14 & CD14 antigen & Increased survival & Oakley et al. 2009 \\
\hline $\mathrm{Cd} 40 / \mathrm{Cd} 40 \mathrm{l}$ & CD40 antigen/ligand & Increased survival & Piguet et al. 2001 \\
\hline Fas & Fas $^{\text {lpr }}$ (hypomorph) & Increased survival & Ohno et al. 2005 \\
\hline Gpxl & Glutathione peroxidase & None & Potter et al. 2005 \\
\hline$H c$ & Hemolytic complement, C5 & Increased survival & Patel et al. 2008 \\
\hline Icaml & Intracellular adhesion factor 1 & Increased survival & Li et al. 2003 \\
\hline Ifng & Interferon $\gamma$ & Increased survival & $\begin{array}{l}\text { Amani et al. 2000; Evans et al. 2006; } \\
\text { Yanez et al. } 1996\end{array}$ \\
\hline Illr & Interleukin 1 receptor & None & Reimer et al. 2010 \\
\hline Il4 & Interleukin 4 & Decreased parasitemia & Saeftel et al. 2004 \\
\hline Irf1 & Interferon responsive factor 1 & Increased survival & Senaldi et al. 1999 \\
\hline Lta & Lymphotoxin A & Increased survival & $\begin{array}{l}\text { Engwerda et al. 2002; Hansen et al. 2004; } \\
\text { Piguet et al. 2002; Stoelcker et al. 2002; } \\
\text { Togbe et al. 2008; Togbe et al. } 2007\end{array}$ \\
\hline$L t b r$ & Lymphotoxin B receptor & Increased survival & Togbe et al. 2008 \\
\hline Myd 88 & Myeloid differentiation primary response & Increased survival (controversial) & Coban et al. 2007; Togbe et al. 2007 \\
\hline Nlrp3 & Nod-like receptor 3 & CM delay & Reimer et al. (2010) \\
\hline Nodl/2 & Nod-like receptor $1 / 2$ & None & Finney et al. 2009 \\
\hline Selp & P-selectin & Increased survival & Combes et al. 2004 \\
\hline Tirap & $\begin{array}{l}\text { Toll-interleukin } 1 \text { receptor domain } \\
\text { containing adaptor }\end{array}$ & None & Coban et al. 2007 \\
\hline $\operatorname{Tl} 1-7$ & Toll-like receptor $1-7$ & None & Coban et al. 2007; Togbe et al. 2007 \\
\hline $\operatorname{Tl} 9$ & Toll-like receptor 9 & Increased survival (controversial) & Coban et al. 2007; Togbe et al. 2007 \\
\hline $\operatorname{Tnf}$ & Tumor necrosis factor $\alpha$ & None & $\begin{array}{l}\text { Engwerda et al. 2002; Hansen et al. 2004; } \\
\text { Togbe et al. } 2008\end{array}$ \\
\hline \multicolumn{4}{|c|}{ Response to stimulus } \\
\hline Ccr5 & Chemokine $(\mathrm{C}-\mathrm{C})$ receptor 5 & Increased survival & Belnoue et al. 2003 \\
\hline Hmoxl & Heme oxygenase 1 & $\begin{array}{l}\text { Decreased survival } \\
\text { in CM-R BALB/c }\end{array}$ & Pamplona et al. 2007 \\
\hline Plat/Plau & Plasminogen activator, tissue/urokinase & None & Piguet et al. 2000 \\
\hline Socs 1 & Suppressor of cytokine signaling 1 & Increased survival & Bullen et al. 2003 \\
\hline \multicolumn{4}{|c|}{ Regulation of biological processes } \\
\hline Caspl & Caspase 1 & None & Reimer et al. 2010 \\
\hline Cxcr3 & Chemokine (C-X-C motif) receptor 3 & Increased survival & $\begin{array}{l}\text { Campanella et al. 2008; Miu et al. 2008; } \\
\text { van den Steen et al. } 2008\end{array}$ \\
\hline Mmp9 & Matrix metallopeptidase 9 & None & van den Steen et al. 2008 \\
\hline Msrl & Macrophage scavenger receptor 1 & None & Cunha-Rodrigues et al. 2006 \\
\hline Nos 3 & Nitric oxide synthase 2 , inducible & None & Gramaglia et al. 2006 \\
\hline Pla2g $4 a$ & Phospholipase A2, group IVA & None & Ishikawa et al. 2004 \\
\hline Socs 2 & Suppressor of cytokine signaling 2 & None & Bullen et al. 2003 \\
\hline \multicolumn{4}{|c|}{ Other (cellular processes, growth, etc.) } \\
\hline Abcal & ATP-binding cassette, A1 & Increased survival & Combes et al. 2005 \\
\hline Asc & PYD/CARD domain containing & None & Reimer et al. 2010 \\
\hline Ttpa & Alpha tocopherol transfer protein & Increased survival & Herbas et al. 2010 \\
\hline Clncl & Chloride channel 1 & None & Huber et al. 2004 \\
\hline
\end{tabular}


Table 4 continued

\begin{tabular}{llll}
\hline Gene ID & Gene name & $\begin{array}{l}\text { Knockout effect on } \\
\text { P. berghei infection }\end{array}$ & Reference \\
\hline Cybb & Cytochrome b-245, B-polypeptide & None & Potter et al. 2005 \\
$H d c$ & Histidine decarboxylase & Increased survival & Beghdadi et al. 2008 \\
$H p$ & Haptoglobin & None & Hunt et al. 2001 \\
Lgals3 & Galectin 3 & Increased survival & Oakley et al. 2009 \\
$P 2 x p 7$ & P2X purinoceptor 7 & None & Reimer et al. 2010 \\
Pfx & Platelet factor 4 & Increased survival & Srivastava et al. 2008 \\
Plaur & Plasminogen activator, urokinase receptor & CM delay & Piguet et al. 2000 \\
Prf & Perforin 1 & Increased survival & Potter et al. 2006 \\
Smpd & Acid sphingomyelinase & Decreased parasitemia & Brand et al. 2008 \\
Trif & Toll-like receptor adaptor molecule & None & Coban et al. 2007 \\
\hline
\end{tabular}

therapeutic potential. While the mapping techniques mentioned above have successfully identified over 15 regions of the genome in mice associated with host resistance, each containing potentially novel genes, most studies have been unsuccessful in identifying these causative genes. In order to utilize the work of these studies and unlock their therapeutic potential, we need to know the actual genes involved with resistance, not simply the chromosomal region where they map.

There is significant promise in the discovery of novel host gene variants that protect against malaria infection. In stark contrast to the problem of parasite resistance to current antimalarial drugs, the development of parasite resistance against the protective polymorphisms found in humans is (virtually) nonexistent [with perhaps one recently discovered exception involving $P$. vivax and Duffy in Madagascar (Menard et al. 2010)]. This is because the basis for the protective effect lies within the host, often modulating the environment of the host erythrocyte. These host cell perturbations affect elements fundamental to the parasite's growth and development. Importantly, protection is governed by the host genome, not the parasite, and thus the parasite is unable to easily develop means to circumvent these changes. This renders such host-protective polymorphisms effectively "parasite-resistance proof." Drugs that mimic such protective mutations or target other host processes essential for parasite survival may similarly avoid parasite drug-resistance problems.

To progress from the genetic loci already identified into such "parasite-resistance proof" antimalarials, new avenues of research need to be explored. The development of genetic data sets tailored for the heterogeneous African populations will allow future genome-wide association studies to be more successful. As our understanding of the host-parasite interactions and kinetics increases, our ability to narrow down large intervals through candidate gene analysis will dramatically improve. The generation of mice with single-point mutations displaying resistance to malaria, developed through mutagenesis screens, will potentially offer a faster route of gene identification than traditional genetic mapping. The resultant possibility of therapies that could be developed will be entirely novel: they will be targeting the host rather than the parasite.

\section{References}

Amani V, Vigario AM, Belnoue E, Marussig M, Fonseca L et al (2000) Involvement of IFN-gamma receptor-mediated signaling in pathology and anti-malarial immunity induced by Plasmodium berghei infection. Eur J Immunol 30:1646-1655

Amante FH, Stanley AC, Randall LM, Zhou Y, Haque A et al (2007) A role for natural regulatory $\mathrm{T}$ cells in the pathogenesis of experimental cerebral malaria. Am J Pathol 171:548-559

Ayi K, Turrini F, Piga A, Arese P (2004) Enhanced phagocytosis of ring-parasitized mutant erythrocytes: a common mechanism that may explain protection against falciparum malaria in sickle trait and beta-thalassemia trait. Blood 104:3364-3371

Ayi K, Min-Oo G, Serghides L, Crockett M, Kirby-Allen M et al (2008) Pyruvate kinase deficiency and malaria. N Engl J Med 358:1805-1810

Bagot S, Campino S, Penha-Goncalves C, Pied S, Cazenave PA et al (2002) Identification of two cerebral malaria resistance loci using an inbred wild-derived mouse strain. Proc Natl Acad Sci USA 99:9919-9923

Beghdadi W, Porcherie A, Schneider BS, Dubayle D, Peronet R et al (2008) Inhibition of histamine-mediated signaling confers significant protection against severe malaria in mouse models of disease. J Exp Med 205:395-408

Belnoue E, Kayibanda M, Deschemin JC, Viguier M, Mack M et al (2003) CCR5 deficiency decreases susceptibility to experimental cerebral malaria. Blood 101:4253-4259

Berghout J, Min-Oo G, Tam M, Gauthier S, Stevenson MM et al (2009) Identification of a novel cerebral malaria susceptibility locus (Berr5) on mouse chromosome 19. Genes Immun 11:310-318

Bongfen SE, Laroque A, Berghout J, Gros P (2009) Genetic and genomic analyses of host-pathogen interactions in malaria. Trends Parasitol 25:417-422

Brand V, Koka S, Lang C, Jendrossek V, Huber SM et al (2008) Influence of amitriptyline on eryptosis, parasitemia and survival 
of Plasmodium berghei-infected mice. Cell Physiol Biochem 22:405-412

Bullen DV, Hansen DS, Siomos MA, Schofield L, Alexander WS et al (2003) The lack of suppressor of cytokine signalling-1 (SOCS1) protects mice from the development of cerebral malaria caused by Plasmodium berghei ANKA. Parasite Immunol 25:113-118

Burt RA, Baldwin TM, Marshall VM, Foote SJ (1999) Temporal expression of an $\mathrm{H} 2$-linked locus in host response to mouse malaria. Immunogenetics 50:278-285

Campanella GS, Tager AM, El Khoury JK, Thomas SY, Abrazinski TA et al (2008) Chemokine receptor CXCR3 and its ligands CXCL9 and CXCL10 are required for the development of murine cerebral malaria. Proc Natl Acad Sci USA 105:4814-4819

Campino S, Bagot S, Bergman ML, Almeida P, Sepulveda N et al (2005) Genetic control of parasite clearance leads to resistance to Plasmodium berghei ANKA infection and confers immunity. Genes Immun 6:416-421

Carvalho LJ (2010) Murine cerebral malaria: how far from human cerebral malaria? Trends Parasitol 26:271-272

Coban C, Ishii KJ, Uematsu S, Arisue N, Sato S et al (2007) Pathological role of Toll-like receptor signaling in cerebral malaria. Int Immunol 19:67-79

Combes V, Rosenkranz AR, Redard M, Pizzolato G, Lepidi H et al (2004) Pathogenic role of P-selectin in experimental cerebral malaria: importance of the endothelial compartment. Am J Pathol 164:781-786

Combes V, Coltel N, Alibert M, van Eck M, Raymond C et al (2005) $A B C A 1$ gene deletion protects against cerebral malaria: potential pathogenic role of microparticles in neuropathology. Am J Pathol 166:295-302

Cox D, McConkey S (2010) The role of platelets in the pathogenesis of cerebral malaria. Cell Mol Life Sci 67:557-568

Cunha-Rodrigues M, Portugal S, Febbraio M, Mota MM (2006) Infection by and protective immune responses against Plasmodium berghei ANKA are not affected in macrophage scavenger receptors A deficient mice. BMC Microbiol 6:73

Darvasi A, Soller M (1995) Advanced intercross lines, an experimental population for fine genetic mapping. Genetics 141:1199-1207

de Souza JB, Hafalla JC, Riley EM, Couper KN (2010) Cerebral malaria: why experimental murine models are required to understand the pathogenesis of disease. Parasitology 137:755-772

Delahaye NF, Coltel N, Puthier D, Flori L, Houlgatte R et al (2006) Gene-expression profiling discriminates between cerebral malaria (CM)-susceptible mice and CM-resistant mice. J Infect Dis 193:312-321

Delic D, Warskulat U, Borsch E, Al-Qahtani S, Al-Quraishi S et al (2010) Loss of ability to self-heal malaria upon taurine transporter deletion. Infect Immun 78:1642-1649

Dondorp AM, Nosten F, Yi P, Das D, Phyo AP et al (2009) Artemisinin resistance in Plasmodium falciparum malaria. N Engl J Med 361:455-467

Engwerda CR, Mynott TL, Sawhney S, De Souza JB, Bickle QD et al (2002) Locally up-regulated lymphotoxin alpha, not systemic tumor necrosis factor alpha, is the principal mediator of murine cerebral malaria. J Exp Med 195:1371-1377

Evans KJ, Hansen DS, van Rooijen N, Buckingham LA, Schofield L (2006) Severe malarial anemia of low parasite burden in rodent models results from accelerated clearance of uninfected erythrocytes. Blood 107:1192-1199

Finney CA, Lu Z, LeBourhis L, Philpott DJ, Kain KC (2009) Disruption of Nod-like receptors alters inflammatory response to infection but does not confer protection in experimental cerebral malaria. Am J Trop Med Hyg 80:718-722
Flint J, Hill AV, Bowden DK, Oppenheimer SJ, Sill PR et al (1986) High frequencies of alpha-thalassaemia are the result of natural selection by malaria. Nature 321:744-750

Foote SJ, Burt RA, Baldwin TM, Presente A, Roberts AW et al (1997) Mouse loci for malaria-induced mortality and the control of parasitaemia. Nat Genet 17:380-381

Fortin A, Belouchi A, Tam MF, Cardon L, Skamene E et al (1997) Genetic control of blood parasitaemia in mouse malaria maps to chromosome 8. Nat Genet 17:382-383

Fortin A, Cardon LR, Tam M, Skamene E, Stevenson MM et al (2001) Identification of a new malaria susceptibility locus (Char4) in recombinant congenic strains of mice. Proc Natl Acad Sci USA 98:10793-10798

Fortin A, Stevenson MM, Gros P (2002) Complex genetic control of susceptibility to malaria in mice. Genes Immun 3:177-186

Francischetti IM (2008) Does activation of the blood coagulation cascade have a role in malaria pathogenesis? Trends Parasitol $24: 258-263$

Friedman MJ (1978) Erythrocytic mechanism of sickle cell resistance to malaria. Proc Natl Acad Sci USA 75:1994-1997

Gramaglia I, Sobolewski P, Meays D, Contreras R, Nolan JP et al (2006) Low nitric oxide bioavailability contributes to the genesis of experimental cerebral malaria. Nat Med 12:1417-1422

Greenberg J, Nadel EM, Coatney GR (1954) Differences in survival of several inbred strains of mice and their hybrids infected with Plasmodium berghei. J Infect Dis 95:114-116

Haldane JBS (1949) The rate of mutation of human genes. Proceedings of the Eighth International Congress of Genetics. Hereditas 35:267-273

Hansen AM, Ball HJ, Mitchell AJ, Miu J, Takikawa O et al (2004) Increased expression of indoleamine 2,3-dioxygenase in murine malaria infection is predominantly localised to the vascular endothelium. Int J Parasitol 34:1309-1319

Hansen DS, Siomos MA, Buckingham L, Scalzo AA, Schofield L (2003) Regulation of murine cerebral malaria pathogenesis by CD1d-restricted NKT cells and the natural killer complex. Immunity 18:391-402

Herbas MS, Okazaki M, Terao E, Xuan X, Arai H et al (2010) alphaTocopherol transfer protein inhibition is effective in the prevention of cerebral malaria in mice. Am $\mathrm{J}$ Clin Nutr 91:200-207

Hernandez-Valladares M, Naessens J, Gibson JP, Musoke AJ, Nagda S et al (2004a) Confirmation and dissection of QTL controlling resistance to malaria in mice. Mamm Genome 15:390-398

Hernandez-Valladares M, Rihet P, Ole-MoiYoi OK, Iraqi FA (2004b) Mapping of a new quantitative trait locus for resistance to malaria in mice by a comparative mapping approach with human Chromosome 5q31-q33. Immunogenetics 56:115-117

Hernandez-Valladares M, Naessens J, Iraqi FA (2005) Genetic resistance to malaria in mouse models. Trends Parasitol $21: 352-355$

Hill AV, Allsopp CE, Kwiatkowski D, Anstey NM, Twumasi P et al (1991) Common west African HLA antigens are associated with protection from severe malaria. Nature 352:595-600

Hisaeda H, Tetsutani K, Imai T, Moriya C, Tu L et al (2008) Malaria parasites require TLR9 signaling for immune evasion by activating regulatory T cells. J Immunol 180:2496-2503

Huber SM, Duranton C, Henke G, Van De Sand C, Heussler V et al (2004) Plasmodium induces swelling-activated ClC-2 anion channels in the host erythrocyte. J Biol Chem 279:41444-41452

Hunt NH, Driussi C, Sai-Kiang L (2001) Haptoglobin and malaria. Redox Rep 6:389-392

Hunt NH, Golenser J, Chan-Ling T, Parekh S, Rae C et al (2006) Immunopathogenesis of cerebral malaria. Int $\mathrm{J}$ Parasitol 36:569-582 
Hunt NH, Grau GE, Engwerda C, Barnum SR, van der Heyde H et al (2010) Murine cerebral malaria: the whole story. Trends Parasitol 26:272-274

Ing R, Gros P, Stevenson MM (2005) Interleukin-15 enhances innate and adaptive immune responses to blood-stage malaria infection in mice. Infect Immun 73:3172-3177

Ishikawa S, Uozumi N, Shiibashi T, Izumi T, Fukayama $\mathrm{M}$ et al (2004) Short report: Lethal malaria in cytosolic phospholipase A2- and phospholipase A2IIA-deficient mice. Am J Trop Med Hyg 70:645-650

Jallow M, Teo YY, Small KS, Rockett KA, Deloukas P et al (2009) Genome-wide and fine-resolution association analysis of malaria in West Africa. Nat Genet 41(6):657-665

Jarolim P, Palek J, Amato D, Hassan K, Sapak P et al (1991) Deletion in erythrocyte band 3 gene in malaria-resistant Southeast Asian ovalocytosis. Proc Natl Acad Sci USA 88:11022-11026

Kwiatkowski DP, Luoni G (2006) Host genetic factors in resistance and susceptibility to malaria. Parassitologia 48:450-467

Lamb TJ, Brown DE, Potocnik AJ, Langhorne J (2006) Insights into the immunopathogenesis of malaria using mouse models. Expert Rev Mol Med 8:1-22

Li J, Chang WL, Sun G, Chen HL, Specian RD et al (2003) Intercellular adhesion molecule 1 is important for the development of severe experimental malaria but is not required for leukocyte adhesion in the brain. J Investig Med 51:128-140

Lin E, Pappenfuss T, Tan RB, Senyschyn D, Bahlo M et al (2006) Mapping of the Plasmodium chabaudi resistance locus char2. Infect Immun 74:5814-5819

Lovegrove FE, Gharib SA, Patel SN, Hawkes CA, Kain KC et al (2007) Expression microarray analysis implicates apoptosis and interferon-responsive mechanisms in susceptibility to experimental cerebral malaria. Am J Pathol 171:1894-1903

McDevitt MA, Xie J, Shanmugasundaram G, Griffith J, Liu A et al (2006) A critical role for the host mediator macrophage migration inhibitory factor in the pathogenesis of malarial anemia. J Exp Med 203:1185-1196

McGuire W, Hill AV, Allsopp CE, Greenwood BM, Kwiatkowski D (1994) Variation in the TNF-alpha promoter region associated with susceptibility to cerebral malaria. Nature 371:508-510

Menard D, Barnadas C, Bouchier C, Henry-Halldin C, Gray LR et al (2010) Plasmodium vivax clinical malaria is commonly observed in Duffy-negative Malagasy people. Proc Natl Acad Sci USA 107:5967-5971

Min-Oo G, Fortin A, Tam MF, Nantel A, Stevenson MM et al (2003) Pyruvate kinase deficiency in mice protects against malaria. Nat Genet 35:357-362

Min-Oo G, Fortin A, Tam MF, Gros P, Stevenson MM (2004) Phenotypic expression of pyruvate kinase deficiency and protection against malaria in a mouse model. Genes Immun 5:168-175

Min-Oo G, Fortin A, Pitari G, Tam M, Stevenson MM et al (2007a) Complex genetic control of susceptibility to malaria: positional cloning of the Char9 locus. J Exp Med 204:511-524

Min-Oo G, Tam M, Stevenson MM, Gros P (2007b) Pyruvate kinase deficiency: correlation between enzyme activity, extent of hemolytic anemia and protection against malaria in independent mouse mutants. Blood Cells Mol Dis 39:63-69

Min-Oo G, Willemetz A, Tam M, Canonne-Hergaux F, Stevenson MM et al (2010) Mapping of Char10, a novel malaria susceptibility locus on mouse chromosome 9. Genes Immun 11:113-123

Mishra SK, Newton CR (2009) Diagnosis and management of the neurological complications of falciparum malaria. Nat Rev Neurol 5:189-198

Miu J, Mitchell AJ, Muller M, Carter SL, Manders PM et al (2008) Chemokine gene expression during fatal murine cerebral malaria and protection due to CXCR3 deficiency. J Immunol 180:1217-1230

Mullerova J, Hozak P (2004) Use of recombinant congenic strains in mapping disease-modifying genes. News Physiol Sci 19:105-109

Nagayasu E, Nagakura K, Akaki M, Tamiya G, Makino S et al (2002) Association of a determinant on mouse chromosome 18 with experimental severe Plasmodium berghei malaria. Infect Immun 70:512-516

Nielsen PJ, Lorenz B, Muller AM, Wenger RH, Brombacher F et al (1997) Altered erythrocytes and a leaky block in B-cell development in. Blood 89:1058-1067

Oakley MS, Majam V, Mahajan B, Gerald N, Anantharaman V et al (2009) Pathogenic roles of CD14, galectin-3, and OX40 during experimental cerebral malaria in mice. PLoS One 4:e6793

Ohno T, Nishimura M (2004) Detection of a new cerebral malaria susceptibility locus, using CBA mice. Immunogenetics 56:675-678

Ohno T, Ishih A, Kohara Y, Yonekawa H, Terada M et al (2001) Chromosomal mapping of the host resistance locus to rodent malaria (Plasmodium yoelii) infection in mice. Immunogenetics 53:736-740

Ohno T, Kobayashi F, Nishimura M (2005) Fas has a role in cerebral malaria, but not in proliferation or exclusion of the murine parasite in mice. Immunogenetics 57:293-296

Pamplona A, Ferreira A, Balla J, Jeney V, Balla G et al (2007) Heme oxygenase-1 and carbon monoxide suppress the pathogenesis of experimental cerebral malaria. Nat Med 13:703-710

Patel SN, Berghout J, Lovegrove FE, Ayi K, Conroy A et al (2008) C5 deficiency and C5a or C5aR blockade protects against cerebral malaria. J Exp Med 205:1133-1143

Pennacchio LA (2003) Insights from human/mouse genome comparisons. Mamm Genome 14:429-436

Piguet PF, Da Laperrousaz C, Vesin C, Tacchini-Cottier F, Senaldi G et al (2000) Delayed mortality and attenuated thrombocytopenia associated with severe malaria in urokinase- and urokinase receptor-deficient mice. Infect Immun 68:3822-3829

Piguet PF, Kan CD, Vesin C (2002) Role of the tumor necrosis factor receptor 2 (TNFR2) in cerebral malaria in mice. Lab Invest 82:1155-1166

Piguet PF, Kan CD, Vesin C, Rochat A, Donati Y et al (2001) Role of CD40-CVD40L in mouse severe malaria. Am J Pathol 159:733-742

Potter S, Chan-Ling T, Ball HJ, Mansour H, Mitchell A et al (2006) Perforin mediated apoptosis of cerebral microvascular endothelial cells during experimental cerebral malaria. Int $\mathrm{J}$ Parasitol 36:485-496

Potter SM, Mitchell AJ, Cowden WB, Sanni LA, Dinauer M et al (2005) Phagocyte-derived reactive oxygen species do not influence the progression of murine blood-stage malaria infections. Infect Immun 73:4941-4947

Rank G, Sutton R, Marshall V, Lundie RJ, Caddy J et al (2009) Novel roles for erythroid Ankyrin-1 revealed through an ENU-induced null mouse mutant. Blood 113(14):3352-3362

Reimer T, Shaw MH, Franchi L, Coban C, Ishii KJ et al (2010) Experimental cerebral malaria progresses independently of the Nlrp3 inflammasome. Eur J Immunol 40:764-769

Renia L, Gruner AC, Snounou G (2010) Cerebral malaria: in praise of epistemes. Trends Parasitol 26:275-277

Riley EM, Couper KN, Helmby H, Hafalla JC, de Souza JB et al (2010) Neuropathogenesis of human and murine malaria. Trends Parasitol 26:277-278

Riopel J, Tam M, Mohan K, Marino MW, Stevenson MM (2001) Granulocyte-macrophage colony-stimulating factor-deficient mice have impaired resistance to blood-stage malaria. Infect Immun 69:129-136 
Ruwende C, Hill A (1998) Glucose-6-phosphate dehydrogenase deficiency and malaria. J Mol Med 76:581-588

Saeftel M, Krueger A, Arriens S, Heussler V, Racz P et al (2004) Mice deficient in interleukin-4 (IL-4) or IL-4 receptor alpha have higher resistance to sporozoite infection with Plasmodium berghei (ANKA) than do naive wild-type mice. Infect Immun 72:322-331

Sanni LA, Jarra W, Li C, Langhorne J (2004) Cerebral edema and cerebral hemorrhages in interleukin-10-deficient mice infected with Plasmodium chabaudi. Infect Immun 72:3054-3058

Senaldi G, Shaklee CL, Guo J, Martin L, Boone T et al (1999) Protection against the mortality associated with disease models mediated by TNF and IFN-gamma in mice lacking IFN regulatory factor-1. J Immunol 163:6820-6826

Sexton AC, Good RT, Hansen DS, D’Ombrain MC, Buckingham L et al (2004) Transcriptional profiling reveals suppressed erythropoiesis, up-regulated glycolysis, and interferon-associated responses in murine malaria. J Infect Dis 189:1245-1256

Shear HL, Roth E Jr, Ng C, Nagel RL (1991) Resistance to malaria in ankyrin and spectrin deficient mice. Br J Haematol 78:555-560

Srivastava K, Cockburn IA, Swaim A, Thompson LE, Tripathi A et al (2008) Platelet factor 4 mediates inflammation in experimental cerebral malaria. Cell Host Microbe 4:179-187

Stevenson MM, Gros P, Olivier M, Fortin A, Serghides L (2010) Cerebral malaria: human versus mouse studies. Trends Parasitol 26:274-275

Stoelcker B, Hehlgans T, Weigl K, Bluethmann H, Grau GE et al (2002) Requirement for tumor necrosis factor receptor 2 expression on vascular cells to induce experimental cerebral malaria. Infect Immun 70:5857-5859

Togbe D, Schofield L, Grau GE, Schnyder B, Boissay V et al (2007) Murine cerebral malaria development is independent of toll-like receptor signaling. Am J Pathol 170:1640-1648

Togbe D, de Sousa PL, Fauconnier M, Boissay V, Fick L et al (2008) Both functional LTbeta receptor and TNF receptor 2 are required for the development of experimental cerebral malaria. PLoS One 3:e2608
Tournamille C, Colin Y, Cartron JP, Le Van Kim C (1995) Disruption of a GATA motif in the Duffy gene promoter abolishes erythroid gene expression in Duffy-negative individuals. Nat Genet 10:224-228

van den Steen PE, Deroost K, Van Aelst I, Geurts N, Martens E et al (2008) CXCR3 determines strain susceptibility to murine cerebral malaria by mediating $\mathrm{T}$ lymphocyte migration toward IFN-gamma-induced chemokines. Eur J Immunol 38:1082-1095

van der Heyde HC, Pepper B, Batchelder J, Cigel F, Weidanz WP (1997) The time course of selected malarial infections in cytokine-deficient mice. Exp Parasitol 85:206-213

van der Heyde HC, Nolan J, Combes V, Gramaglia I, Grau GE (2006) A unified hypothesis for the genesis of cerebral malaria: sequestration, inflammation and hemostasis leading to microcirculatory dysfunction. Trends Parasitol 22:503-508

Verra F, Mangano VD, Modiano D (2009) Genetics of susceptibility to Plasmodium falciparum: from classical malaria resistance genes towards genome-wide association studies. Parasite Immunol 31:234-253

Weatherall DJ, Miller LH, Baruch DI, Marsh K, Doumbo OK et al (2002) Malaria and the red cell. Hematology Am Soc Hematol Educ Program 2002:35-57

White NJ, Turner GD, Medana IM, Dondorp AM, Day NP (2010) The murine cerebral malaria phenomenon. Trends Parasitol 26:11-15

Williams TN, Maitland K, Bennett S, Ganczakowski M, Peto TE et al (1996) High incidence of malaria in alpha-thalassaemic children. Nature 383:522-525

Wunderlich F, Mossmann H, Helwig M, Schillinger G (1988) Resistance to Plasmodium chabaudi in B10 mice: influence of the H-2 complex and testosterone. Infect Immun 56:2400-2406

Yanez DM, Manning DD, Cooley AJ, Weidanz WP, van der Heyde HC (1996) Participation of lymphocyte subpopulations in the pathogenesis of experimental murine cerebral malaria. J Immunol 157:1620-1624 